\title{
L-type $\mathrm{Ca}^{2+}$ channel function during Timothy Syndrome
}

\author{
Rose E. Dixon, Edward P. Cheng, José L. Mercado, and Luis F. Santana \\ Department of Physiology \& Biophysics, University of Washington, Seattle, WA 98195
}

\begin{abstract}
Voltage-gated, dihydropyridine-sensitive L-type $\mathrm{Ca}^{2+}$ channels are multmeric proteins composed of a pore-forming transmembrane $\alpha_{1}$ subunit $\left(\mathrm{Ca}_{V} 1.2\right)$ and accessory $\beta, a_{2} \delta$ and $\gamma$ subunits. $\mathrm{Ca}^{2+}$ entry via $\mathrm{Ca}_{V} 1.2$ channels shapes the action potential (AP) of cardiac myocytes and is required for excitation-contraction coupling. Two de novo point mutations of $\mathrm{Ca}_{\mathrm{V}} 1.2$ glycine residues, G406R and G402S, cause a rare multi-system disorder called Timothy syndrome (TS). Here, we discuss recent work on the mechanisms by which $\mathrm{Ca}_{\mathrm{V}} 1.2$ channels bearing TS mutations display slowed inactivation that leads to increased $\mathrm{Ca}^{2+}$ influx, prolonging the cardiac AP and promoting lethal arrhythmias. Based on these studies, we propose a model in which the scaffolding protein AKAP79/150 stabilizes the open conformation of $\mathrm{Ca}_{\mathrm{V}} 1.2-\mathrm{TS}$ channels and facilitates physical interactions among adjacent channels via their $\mathrm{C}$-tails, increasing the activity of adjoining channels and amplifying $\mathrm{Ca}^{2+}$ influx.
\end{abstract}

\section{Introduction}

L-type $\mathrm{Ca}^{2+}\left(\mathrm{Ca}_{\mathrm{V}} 1.2\right)$ channels are expressed in many excitable cell types including neurons, smooth muscle, and cardiac myocytes (Catterall 2000). In the heart, $\mathrm{Ca}^{2+}$ influx via $\mathrm{Ca}_{V} 1.2$ channels shapes the atrial and ventricular action potential (AP) and is essential for excitation-contraction coupling. Thus, changes in $\mathrm{Ca}_{\mathrm{V}} 1.2$ channel function have important implications for excitability and cardiac output.

An example of a pathological condition associated with aberrant $\mathrm{Ca}_{\mathrm{V}} 1.2$ channel gating is Timothy syndrome (TS). TS is a rare, autosomal dominant, multi-organ disorder caused by de novo gain-of-function missense mutations in exon 8 or an alternatively spliced exon $8 \mathrm{~A}$ of Ca 1.2 (Splawski et al. 2005; Splawski et al. 2004). A glycine to arginine substitution at position 406 (G406R) located at the junction between DI/S6 and the I-II loop produces TS1 and TS2 (Splawski et al. 2005; Splawski et al. 2004). The G406R mutant accompanied by another glycine to serine substitution at position 402 (G402S) produces a variant of TS2 (Figure 1A).

TS is characterized by an prolongation of the electrocardiogram QT interval, which is why it is also known as long QT syndrome 8 (LQT8). TS patients commonly suffer sudden cardiac death (SCD) resulting from lethal cardiac arrhythmias (Splawski et al. 2005). The multisystem spectrum of the disease includes congenital heart disease, syndactyly, immunodeficiency, cognitive abnormalities, and autism. Here, we discuss the findings and

\footnotetext{
(c) 2012 Elsevier Inc. All rights reserved.

Corresponding Author: Luis F. Santana, PhD, Department of Physiology \& Biophysics, University of Washington, 1705 NE Pacific St HSB-G424, Box 357290, Seattle WA 98195, Tel: 206-543-8681, santana@uw.edu.

Publisher's Disclaimer: This is a PDF file of an unedited manuscript that has been accepted for publication. As a service to our customers we are providing this early version of the manuscript. The manuscript will undergo copyediting, typesetting, and review of the resulting proof before it is published in its final citable form. Please note that during the production process errors may be discovered which could affect the content, and all legal disclaimers that apply to the journal pertain.
} 
implications of recent studies examining $\mathrm{Ca}_{\mathrm{V}} 1.2$ channel function during TS and suggest a new model of Cav1.2 channel dysfunction during this pathological condition.

\section{TS $\mathrm{Ca}_{\mathrm{V}} 1.2$ channels are hyperactive and have severely impaired VDI}

$\mathrm{Ca}_{V} 1.2$ channels inactivate via voltage (VDI)- and $\mathrm{Ca}^{2+}$-dependent (CDI) mechanisms. In combination, $\mathrm{CDI}$ and VDI limit the open duration of $\mathrm{Ca}_{\mathrm{V}} 1.2$ channels and thus the amount of $\mathrm{Ca}^{2+}$ that enters the cell, shortening AP duration, and protecting cells from $\mathrm{Ca}^{2+}$ overload (Orrenius et al. 2003). Whole-cell TS Ca 1.2 channel (Ca $1.2-T S$ ) currents are larger and inactivate at a slower rate than WT channels (Splawski et al. 2004) (Figure 1B). Analysis of single $\mathrm{Ca}_{\mathrm{V}} 1.2$-TS currents revealed that these channels open more frequently and for longer times than their WT counterparts (Cheng et al. 2011; Dixon et al. 2012; Erxleben et al. 2006). Decreased VDI of Cav1.2-TS channels contributes to the longer mean open times of these channels (Barrett and Tsien 2008). The effect of TS mutations on CDI is still unresolved, with studies suggesting the G406R mutation does not alter, increases, or decreases CDI (Barrett and Tsien 2008; Raybaud et al. 2006; Splawski et al. 2005; Zhu and Clancy 2007). Nonetheless, these data suggest that increased $\mathrm{Ca}^{2+}$ influx during TS results from an increase in the open probability and open time of $\mathrm{Ca}_{\mathrm{V}} 1.2$ channels.

\section{Clustering and heterogeneity in TS channel activity}

We used optical approaches to image " $\mathrm{Ca}^{2+}$ sparklets" resulting from the influx of $\mathrm{Ca}^{2+}$ via single or small clusters of $\mathrm{Ca}_{\mathrm{V}} 1.2-\mathrm{WT}$ and $\mathrm{Ca}_{\mathrm{V}} 1.2$-TS channels throughout the sarcolemma of ventricular myocytes (Cheng et al. 2011; Dixon et al. 2012; Navedo et al. 2010). The number and activity of sparklet sites was higher in cells expressing TS than WT channels. Furthermore, zones of high $\mathrm{Ca}^{2+}$ sparklet activity were produced by repetitive openings of clusters of up to six WT or TS channels (Dixon et al. 2012; Navedo et al. 2010).

Three independent lines of evidence support a molecular model where these clusters of $\mathrm{Ca}_{\mathrm{V}} 1.2$ channels undergo physical interactions. First, FRET analysis between WT and TS channels fluorescently tagged at their C-terminus support the view that the C-tails of these channels do come into close proximity $(<60 \mathrm{~nm})$ of one another potentially allowing them to physically interact (Dixon et al. 2012; Navedo et al. 2010). Second, C-terminal fragments of cardiac $\mathrm{Ca}_{\mathrm{V}} 1.2$ channels dimerize via $\mathrm{Ca}^{2+} \cdot \mathrm{CaM}$ bridges (Fallon et al. 2009). Third, stable dimers have been isolated from purified cardiac or skeletal muscle L-type $\mathrm{Ca}^{2+}$ channels (Fallon et al. 2009; Hymel et al. 1988; Wang et al. 2004; Wang et al. 2002).

\section{Allosteric amplification of $\mathrm{Ca}^{2+}$ influx via TS and WT channels}

We recently used optogenetics to investigate the functional implications of clustering and Ctail-to-C-tail interactions among Cav1.2 channels (Dixon et al. 2012; Yazawa et al. 2009). In these experiments, light was used to fuse $\mathrm{Ca}_{\mathrm{V}} 1.2$ channels with the proteins GIGANTEA (GI) or FLAVIN-BINDING KELTCH REPEAT F BOX 1 (FKF1) linked to the C-tails (Figure 2). Light-induced fusion of Cav 1.2 channels led to increased $\mathrm{Ca}^{2+}$ currents $\left(\mathrm{I}_{\mathrm{Ca}}\right)$ and thus amplification of $\mathrm{Ca}^{2+}$ influx. The efficiency of channel fusion is dependent on the relative abundance of $\mathrm{Ca}_{\mathrm{V}} 1.2-\mathrm{FKF} 1$ and $\mathrm{Ca}_{\mathrm{V}}$ 1.2-GI channels so to determine the relative expression of each of the tagged channels, we made one set of the tagged channels dihydropyridine-insensitive (DHP-ins). Application of nifedipine would then inhibit only the dihydropyridine-sensitive channels. Detailed biophysical analysis of whole-cell and elementary $\mathrm{Ca}_{\mathrm{v}} 1.2$ currents suggested that light-induced fusion of $\mathrm{Ca}_{\mathrm{V}} 1.2$ channels increases $\mathrm{Ca}^{2+}$ influx by increasing the activity (Figure 2A(i)) and coupling — albeit weakly — of these channels (Figure 2A(ii)) (Dixon et al. 2012). 
These results led us to propose that $\mathrm{Ca}_{\mathrm{v}} 1.2$ channels could become allosteric activators of neighboring $\mathrm{Ca}_{\mathrm{v}} 1.2$ channels upon $\mathrm{C}$-tail $-\mathrm{C}$-tail interaction, leading to increased $\mathrm{Ca}^{2+}$ influx. Furthermore, we proposed that these physical interactions could increase $\mathrm{Ca}^{2+}$ influx via two complementary mechanisms. Firstly, C-tail interactions increase the positive cooperativity of the adjoined channels (Figure 2A(ii)) and this then promotes a switch from a predominantly stochastic gating modality to one where coupling openings become more likely (Dixon et al. 2012). In the absence of a forced interaction of channels such as the light-activated fusion system, we have previously reported that activators of PKCa or calmodulin $(\mathrm{CaM})$ antagonists that move CaM away from the IQ motif on the Cav1.2 C-tail promote coupled gating between $\mathrm{Ca}_{V} 1.2$ channels (Navedo et al. 2010). We presume that this increased coupled gating occurs as a result of transient interactions between channels via their $\mathrm{C}$-tails in a mechanism similar to that discussed above.

Physical interactions between CaV1.2 channels had an intriguing effect on adjoined channels: fusion of intrinsically hyperactive TS channels to WT channels induced WT channels to function like TS channels, suggesting that higher open probability channels (in our case $\mathrm{Ca}_{\mathrm{v}} 1.2$-TS channels) are likely to determine the level of activity of adjoining channels within a cluster. An example of this is shown in Figure 2B(i). Light-induced fusion was performed on cells expressing both DHPins-TS and WT channels. Upon fusion an increase in peak $\mathrm{I}_{\mathrm{Ca}}$ was observed as with the fusion of the WT channels, but intriguingly, we also observed an increase in the non-inactivating component of the $\mathrm{I}_{\mathrm{Ca}}$. The characteristic non-inactivating component of TS channels is caused by their slower rate of inactivation compared to WT channels (as detailed above), and the non-scalar increase in this component (Figure 2B(i) inset) suggested that the TS channels to which they were fused drove the WT channels' gating. Consistent with this, we found that inhibition of Cav1.2-WT channels with nifedipine following fusion to DHPins-Cav1.2-TS channels led to a reduction in the non-inactivating component back to the initial pre-fusion level that is entirely due to the DHPins-Cav1.2-TS channels alone (Figure 2B(i)). Furthermore, fusion of Cav1.2-TS and $\mathrm{Ca}_{\mathrm{V}}$ 1.2-WT shifted the voltage dependence of conductance leftwards, towards that observed in cells expressing only Cav1.2-TS, in agreement with the idea that Cav1.2-WT channels become more 'TS-like' and adopt the properties of TS channels whenever they physically interact with one another via their C-tails (Figure 2B(ii)).

These findings have important implications. If TS channels can form stable interactions with neighboring WT channels in TS patients, then this minority of mutant channels (only 23\% of total cardiac $\mathrm{Ca}_{\mathrm{V}} 1.2$ ) could have a disproportionally large effect on $\mathrm{Ca}^{2+}$ influx. We tested this idea in ventricular myocytes expressing our fusible $\mathrm{Ca}_{\mathrm{V}} 1.2$ channels and found that fusion of TS channels with WT channels led to the development of arrhythmogenic spontaneous $\mathrm{SR} \mathrm{Ca}{ }^{2+}$ release events and $\mathrm{Ca}^{2+}$ alternans, in addition to increased amplitude of $\left[\mathrm{Ca}^{2+}\right]_{\mathrm{i}}$ transients and contractions, consistent with the hypothesis that physical interaction between the C-tails of TS and WT channels could produce disproportionally large amounts of $\mathrm{Ca}^{2+}$ influx ultimately inducing arrhythmogenic changes in $\left[\mathrm{Ca}^{2+}\right]_{\mathrm{i}}$ (Dixon et al. 2012).

It is interesting to speculate over how the TS mutation which occurs in Cav1.2 channels at a site distant (I-II loop) from the proposed site of channel interaction at the LZ motif on the Ctail, could lead to increased coupled gating frequency. Although the answer to this conundrum is still unresolved, a recent publication provides some new insight into how these two seemingly distant sites could impact one another. Altier et al. have reported that the Cav1.2 channel distal C-tail directly associates with AKAP79 and that this interaction competes with another interaction between the C-tail and the II-III loop of the channel (Altier et al. 2012). It is tempting to speculate that a similar competition may exist between AKAP150 and the I-II loop of Cav1.2 channels and that perhaps the TS mutation somehow 
tilts the balance in favor of the AKAP150 interaction and promotes channel coupling. Future studies should address this possibility.

\section{AKAP150 is essential for the TS phenotype}

AKAP150, the rodent ortholog of AKAP79, is an $\underline{\mathrm{A}}$-kinase anchoring protein that targets cAMP-dependent protein kinase (PKA), protein kinase $\mathrm{C}(\mathrm{PKC})$ and $\mathrm{Ca}^{2+} / \mathrm{CaM}$-dependent protein phosphatase (PP2B) to regions of the plasma membrane near $\mathrm{Ca}_{\mathrm{V}} 1.2$ channels in ventricular myocytes and neurons (Coghlan et al. 1995; Nichols et al. 2010). A recent study has reported that AKAP79 exists in a dimeric form (Gold et al. 2011). Several investigators have reported that AKAP79/150 forms functional interactions with $\mathrm{Ca}_{\mathrm{V}} 1.2$ channels (Altier et al. 2002; Gao et al. 1997; Hall et al. 2007; Oliveria et al. 2007). In mouse ventricular myocytes, only a subpopulation ( $50 \%)$ of $\mathrm{Ca}_{\mathrm{V}} 1.2$ channels interacts with AKAP150 (Nichols et al. 2010). The interaction sites have been determined to include a site in the $\mathrm{Ca}_{V} 1.2 \mathrm{NH}_{2}$ terminus, one in the I-II loop and another, the site of strongest binding affinity, in the distal C-terminus tail at a leucine zipper (LZ) motif (Hall et al. 2007; Oliveria et al. 2007).

Three important observations suggest that AKAP150 is an important modulator of Cav 1.2 channel function. First, AKAP150 interacts with $\mathrm{Ca}_{\mathrm{V}} 1.2$ channels at the LZ-motif site on the Cterminal (Oliveria et al. 2007). Second, deletion of the distal C-tail of Cav1.2 (including the LZ-motif), eliminates coupled gating of these channels (Navedo et al. 2010). Third, when Cav1.2-TS channels are expressed in mouse embryonic fibroblasts (MEF) isolated from AKAP $150^{-/-}$mice, the whole-cell $\mathrm{I}_{\mathrm{Ca}}$ showed inactivation kinetics indistinguishable from that of WT CaV 1.2 channels, showing that AKAP150 is critical for the development of the TS phenotype (Cheng et al. 2011).

In 2011, two separate, newly developed lines of TS mutant mice were reported (Bader et al. 2011; Cheng et al. 2011). Our lab used the a-myosin heavy chain (aMHC) promoter to produce a cardiac-specific transgenic mouse model of TS, also known as LQT8 mice, in which $\sim 30 \%$ of the sarcolemmal Cav 1.2 channels were Cav1.2-TS.

Currents recorded from ventricular myocytes from LQT8 adult mice exhibited delayed inactivation, characteristic of Cav1.2-TS channels (Figure 1B) (Cheng et al. 2011). However, when LQT8 mice were crossed with AKAP150-/- mice (Tunquist et al. 2008) to produce LQT8/AKAP150 ${ }^{-/}$mice, normal $\mathrm{I}_{\mathrm{Ca}}$ amplitude and kinetics were restored, consistent with the MEF data described above. This suggested that AKAP150 was essential for the slowed Cav1.2 channel inactivation that is typical of TS. Further characterization of the cardiac anatomy and function of these animals revealed that LQT8 mice had significantly hypertrophied hearts and myocytes compared to WT or LQT8/AKAP150 ${ }^{-/-}$ mice. These findings suggest that loss of AKAP150 actually protects against the cardiac hypertrophy associated with TS (Cheng et al. 2011). Cell-attached patch recordings were made to study the effect of AKAP150 on elementary $\mathrm{I}_{\mathrm{Ca}}$, open probability $\left(P_{o}\right)$, open time and coupled gating of Cav 1.2 channels. While the LQT8 mutant myocytes had greater $P_{O}$, open time duration, and coupled gating frequency, ablation of AKAP150 was found to restore WT activity and coupling probability (Cheng et al. 2011).

The most common cause of death in TS is ventricular tachyarrhythmia. Until the development of the LQT8 mouse model, all studies examining the effects of TS on cardiac APs had involved either computer modeling, cardiomyocytes that were virally transduced to express TS channels, or inducible pluripotent stem cells generated from TS patient skin cells (Splawski et al. 2005; Splawski et al. 2004; Thiel et al. 2008; Yazawa et al. 2011). The AP waveform from the LQT8 mouse ventricular myocytes was found to be significantly elongated compared to WT or LQT8/AKAP150 ${ }^{-/-}$myocytes (Cheng et al. 2011). This 
suggests that eliminating AKAP150 could abrogate one of the fundamental characteristics of TS: a prolonged QT interval. This was further evaluated using ECG telemetry recordings in mice. These recordings revealed that although the LQT8 mice have a longer QT interval and higher incidence of exercise-induced arrythmogenic events such as premature ventricular depolarizations and torsades de pointes, none of these events were recorded in WT or LQT8/ $\mathrm{AKAP}^{-/-}$mice. Again, this finding suggests AKAP150 plays a necessary role in arrhythmogenesis during TS. Collectively, these results indicate that AKAP150 is essential for the TS cardiac phenotype and that AKAP150 may be a potential therapeutic target in the treatment of the cardiac manifestations of TS.

\section{A new model for TS channel dysfunction and future directions}

On the basis of these studies, we propose a new model for cardiac Cav 1.2 channel dysfunction during TS. This model is depicted in Figure 3 and shows Cav1.2 channels in a complex with AKAP150. AKAP150 dimers likely interact with Cav1.2 channels via LZmotifs in their C-termini, promoting physical interaction between adjacent channels within the sarcolemma. Presumably TS channels have an increased probability of coupled gating because AKAP150 interacts with these channels in such a way as to stabilize the physical interaction between channels. Future studies should address this and further investigate the molecular interaction between CaV1.2 channels and AKAP150. This coupled gating phenomenon is not exclusive to TS channels. An increased probability of coupled gating events has also been reported in hypertensive smooth muscle cells (Navedo et al 2010). In smooth muscle, the amplified $\mathrm{Ca}^{2+}$ influx produced by coupled openings of $\mathrm{Ca}_{V} 1.2$ channels could directly activate contractile proteins and lead to increased myogenic tone and blood pressure. Therefore, we propose that $\mathrm{Ca}^{2+}$ signaling amplification by coupled gating of $\mathrm{Ca}_{\mathrm{V}} 1.2$ channels is not a unique feature of the rare TS condition but rather, may represent a more general mechanism applicable to excitable cells.

Several unanswered questions that merit further study include: does AKAP150 influence the size and stability of Cav1.2 clusters and oligomers? Is the interaction between AKAP150 and TS channels different from that seen with WT channels? We have hypothesized that the LZ motif on the C-tail is an important interaction site for physical interaction between channels via AKAP150 since coupled gating is absent when the distal C-tail is ablated but is the LZ motif the only site needed for coupled gating or do other sites play a role?

Additionally, elucidation of the mechanism whereby C-tail interactions between clusters of $\mathrm{Ca}_{V} 1.2$ channels translates into opening must be explored.

\section{References}

Altier C, Dubel SJ, Barrere C, Jarvis SE, Stotz SC, Scott JD, Nargeot J, Zamponi GW, Bourinet E. AKAP79 modulation of L-type channels involves disruption of intramolecular interactions in the CaV 1.2 subunit. Channels. 2012; 6(3):1-9.

Altier C, Dubel SJ, Barrere C, Jarvis SE, Stotz SC, Spaetgens RL, Scott JD, Cornet V, De Waard M, Zamponi GW, et al. Trafficking of L-type calcium channels mediated by the postsynaptic scaffolding protein AKAP79. J Biol Chem. 2002; 277:33598-33603. [PubMed: 12114507]

Bader PL, Faizi M, Kim LH, Owen SF, Tadross MR, Alfa RW, Bett GC, Tsien RW, Rasmusson RL, Shamloo M. Mouse model of Timothy syndrome recapitulates triad of autistic traits. Proc Natl Acad Sci U S A. 2011; 108:15432-15437. [PubMed: 21878566]

Barrett CF, Tsien RW. The Timothy syndrome mutation differentially affects voltage- and calciumdependent inactivation of CaV1.2 L-type calcium channels. Proc Natl Acad Sci U S A. 2008; 105:2157-2162. [PubMed: 18250309]

Catterall WA. Structure and regulation of voltage-gated $\mathrm{Ca}^{2+}$ channels. Annu Rev Cell Dev Biol. 2000; 16:521-555. [PubMed: 11031246] 
Cheng EP, Yuan C, Navedo MF, Dixon RE, Nieves-Cintron M, Scott JD, Santana LF. y Restoration of Normal L-Type Ca2+ Channel Function During Timothy Syndrome by Ablation of an Anchoring Protein. Circ Res. 2011; 109:255-261. [PubMed: 21700933]

Coghlan VM, Perrino BA, Howard M, Langeberg LK, Hicks JB, Gallatin WM, Scott JD. Association of protein kinase A and protein phosphatase 2B with a common anchoring protein. Science. 1995; 267:108-111. [PubMed: 7528941]

Dixon RE, Yuan C, Cheng EP, Navedo MF, Santana LF. Ca2+ signaling amplification by oligomerization of L-type Cav1.2 channels. Proc Natl Acad Sci U S A. 2012; 109:1749-1754. [PubMed: 22307641]

Erxleben C, Liao Y, Gentile S, Chin D, Gomez-Alegria C, Mori Y, Birnbaumer L, Armstrong DL. Cyclosporin and Timothy syndrome increase mode 2 gating of CaV1.2 calcium channels through aberrant phosphorylation of S6 helices. Proc Natl Acad Sci U S A. 2006; 103:3932-3937. [PubMed: 16537462]

Fallon JL, Baker MR, Xiong L, Loy RE, Yang G, Dirksen RT, Hamilton SL, Quiocho FA. Crystal structure of dimeric cardiac L-type calcium channel regulatory domains bridged by $\mathrm{Ca}^{2+}$ calmodulins. Proc Natl Acad Sci U S A. 2009; 106:5135-5140. [PubMed: 19279214]

Gao T, Yatani A, Dell'Acqua ML, Sako H, Green SA, Dascal N, Scott JD, Hosey MM. cAMPdependent regulation of cardiac L-type $\mathrm{Ca}^{2+}$ channels requires membrane targeting of PKA and phosphorylation of channel subunits. Neuron. 1997; 19:185-196. [PubMed: 9247274]

Gold MG, Stengel F, Nygren PJ, Weisbrod CR, Bruce JE, Robinson CV, Barford D, Scott JD. Architecture and dynamics of an A-kinase anchoring protein 79 (AKAP79) signaling complex. Proc Natl Acad Sci U S A. 2011; 108:6426-6431. [PubMed: 21464287]

Hall DD, Davare MA, Shi M, Allen ML, Weisenhaus M, McKnight GS, Hell JW. Critical nel role of cAMP-dependent protein kinase anchoring to the L-type calcium chan Cav1.2 via A-kinase anchor protein 150 in neurons. Biochemistry. 2007; 46:1635-1646. [PubMed: 17279627]

Hymel L, Striessnig J, Glossmann H, Schindler H. Purified skeletal muscle 1,4-dihydropyridine receptor forms phosphorylation-dependent oligomeric calcium channels in planar bilayers. Proc Nat Acad Sci USA. 1988; 85:4290-4294. [PubMed: 2454467]

Navedo MF, Cheng EP, Yuan C, Votaw S, Molkentin JD, Scott JD, Santana LF. Increased coupled gating of L-type $\mathrm{Ca}^{2+}$ channels during hypertension and Timothy syndrome. Circ Res. 2010; 106:748-756. [PubMed: 20110531]

Nichols CB, Rossow CF, Navedo MF, Westenbroek RE, Catterall WA, Santana LF, McKnight GS. Sympathetic Stimulation of Adult Cardiomyocytes Requires Association of 6. AKAP5 With a Subpopulation of L-Type Calcium Channels. Circ Res. 2010; 107:747-745. [PubMed: 20671242]

Oliveria SF, Dell'Acqua ML, Sather WA. AKAP79/150 anchoring of calcineurin controls neuronal Ltype $\mathrm{Ca}^{2+}$ channel activity and nuclear signaling. Neuron. 2007; 55:261-275. [PubMed: 17640527]

Orrenius S, Zhivotovsky B, Nicotera P. Regulation of cell death: the calcium-apoptosis link. Nat Rev Mol Cell Biol. 2003; 4:552-565. [PubMed: 12838338]

Raybaud A, Dodier Y, Bissonnette P, Simoes M, Bichet DG, Sauve R, Parent L. The role of the GX9GX3G motif in the gating of high voltage-activated $\mathrm{Ca}^{2+}$ channels. J Biol Chem. 2006; 281:39424-39436. [PubMed: 17038321]

Splawski I, Timothy KW, Decher N, Kumar P, Sachse FB, Beggs AH, Sanguinetti MC, Keating MT. Severe arrhythmia disorder caused by cardiac L-type calcium channel mutations. Proc Natl Acad Sci U S A. 2005; 102:8089-8096. discussion 8086-8. [PubMed: 15863612]

Splawski I, Timothy KW, Sharpe LM, Decher N, Kumar P, Bloise R, Napolitano C, Schwartz PJ, Joseph RM, Condouris $\mathrm{K}$, et al. $\mathrm{Ca}(\mathrm{V}) 1.2$ calcium channel dysfunction causes a multisystem disorder including arrhythmia and autism. Cell. 2004; 119:19-31. [PubMed: 15454078]

Thiel WH, Chen B, Hund TJ, Koval OM, Purohit A, Song LS, Mohler PJ, Anderson ME. Proarrhythmic defects in Timothy syndrome require calmodulin kinase II. Circulation. 2008; 118:2225-2234. [PubMed: 19001023]

Tunquist BJ, Hoshi N, Guire ES, Zhang F, Mullendorff K, Langeberg LK, Raber J, Scott JD. Loss of AKAP150 perturbs distinct neuronal processes in mice. Proc Natl Acad Sci U S A. 2008; 105:12557-12562. [PubMed: 18711127] 
Wang MC, Collins RF, Ford RC, Berrow NS, Dolphin AC, Kitmitto A. The three-dimensional structure of the cardiac L-type voltage-gated calcium channel: comparison with the skeletal muscle form reveals a common architectural motif. J Biol Chem. 2004; 279:7159-7168. [PubMed: 14634003]

Wang MC, Velarde G, Ford RC, Berrow NS, Dolphin AC, Kitmitto A. 3D structure of th skeletal muscle dihydropyridine receptor. J Mol Biol. 2002; 323:85-98. [PubMed: 12368101]

Yazawa M, Hsueh B, Jia X, Pasca AM, Bernstein JA, Hallmayer J, Dolmetsch RE. Using induced pluripotent stem cells to investigate cardiac phenotypes in Timothy syndrome. Nature. 2011; 471:230-234. [PubMed: 21307850]

Yazawa M, Sadaghiani AM, Hsueh B, Dolmetsch RE. Induction of protein-protein interactions in live cells using light. Nat Biotechnol. 2009; 27:941-945. [PubMed: 19801976]

Zhu ZI, Clancy CE. L-type Ca2+ channel mutations and T-wave alternans: a model study. Am J Physiol Heart Circ Physiol. 2007; 293:H3480-H3489. [PubMed: 17933974] 


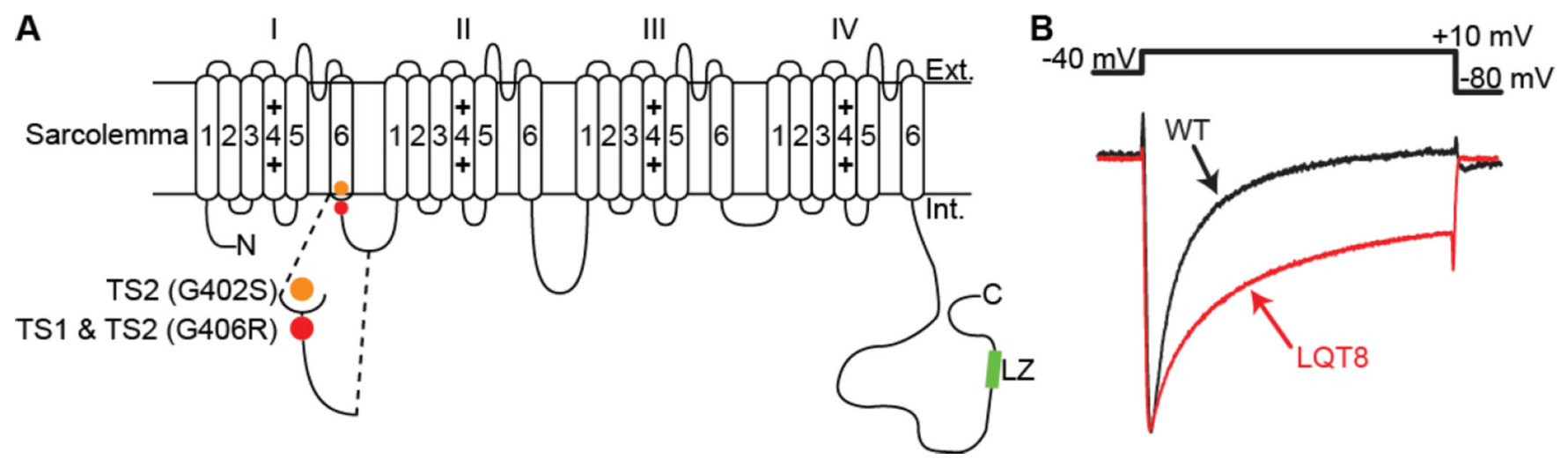

Figure 1. TS channels display impaired inactivation

A: Predicted membrane topology of $\mathrm{Ca}_{\mathrm{V}} 1.2$ showing the location of the mutations associated with TS. B: Normalized whole-cell $\mathrm{Ca}^{2+}$ currents $\left(\mathrm{I}_{\mathrm{Ca}}\right)$ from representative WT and LQT8 ventricular myocytes (modified from Cheng et al. 2011). 
A (i)

B (i) (ii)
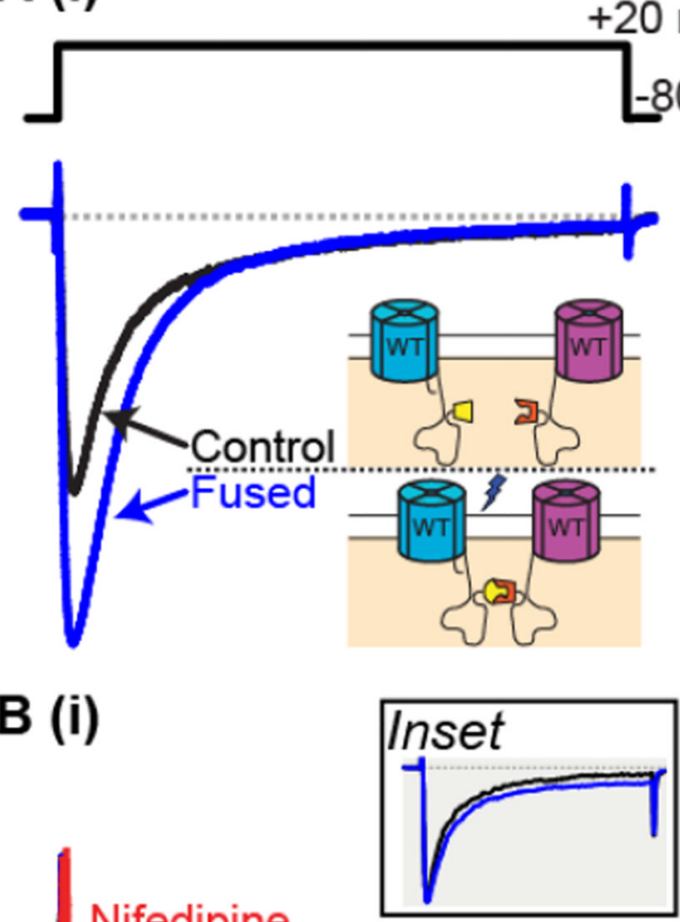

Nifedipine
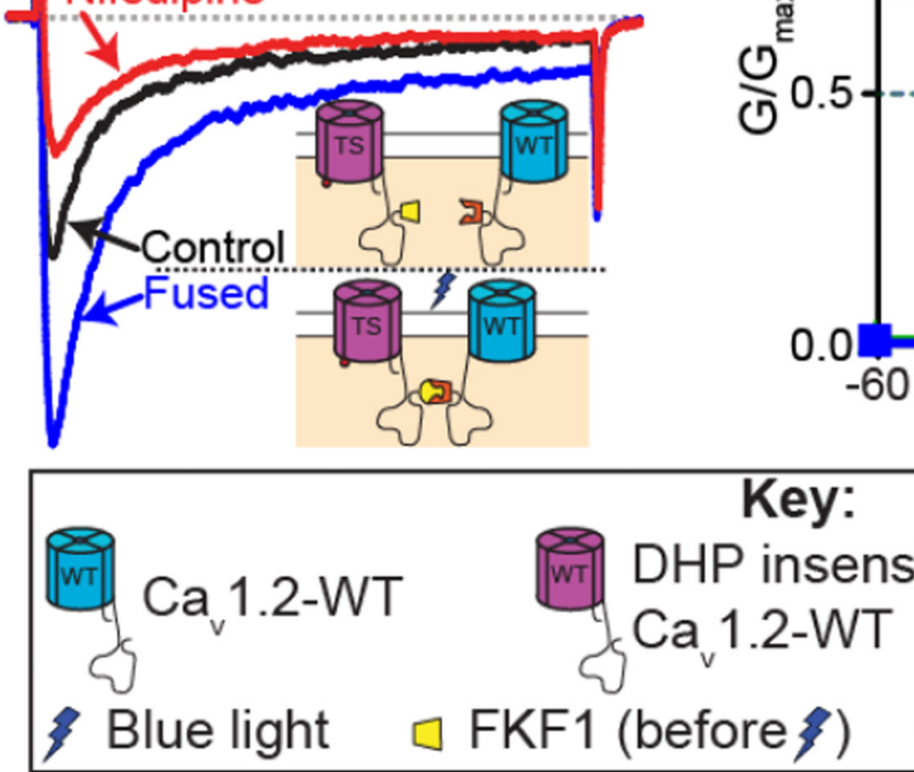

FKF1 (before $)$

$\leadsto$ FKF1 (after $\xi)$

2 $\mathrm{Gl}$

Figure 2. Fusion of Cay1.2 channels

A: (i) Representative $I_{C a}$ records and (ii) voltage dependence of $G / G_{\max }$ from tsA-201 cells expressing the $\mathrm{Ca}_{V} 1.2-\mathrm{FKF} 1$ and dihydropyridine insensitive (DHPins) Cav1.2-GI constructs before and after fusion of the $\mathrm{C}$-tail tagged plant proteins upon illumination with blue light. $\mathrm{B}(\mathrm{i})$ : Representative $\mathrm{I}_{\mathrm{Ca}}$ records and (ii) voltage dependence of $\mathrm{G} / \mathrm{G}_{\max }$ before and after fusion from tsA-201 cells transfected with Cav1.2DHPins-TS-FKF1 and Cav1.2GI. An additional green trace in (ii) shows the voltage dependence of $G / G_{\max }$ from tsA-201 cells transfected with only Cav1.2-TS-FKF1. Currents were elicited with a 300-ms depolarizing step to $+20 \mathrm{mV}$ from a holding potential of $-80 \mathrm{mV}$. Illustrations of the fusion 
principle are shown in each instance whereby FKF1 undergoes a conformational change upon illumination with blue light rendering it capable of binding to GI and forcing physical interaction of the channels. Inset in $\mathrm{B}(\mathrm{i})$ compares the non-inactivating component when the control $\mathrm{I}_{\mathrm{Ca}}$ trace was scaled up to match the peak $\mathrm{I}_{\mathrm{Ca}}$ after fusion. Notice that the increase in the non-inactivating component is non-scalar. Conductance $(\mathrm{G})$ was normalized to the maximum conductance $\left(\mathrm{G}_{\max }\right)$ and fitted with Boltzmann functions. Modified from Dixon et al. 2012. 


\section{Independently gating channels}

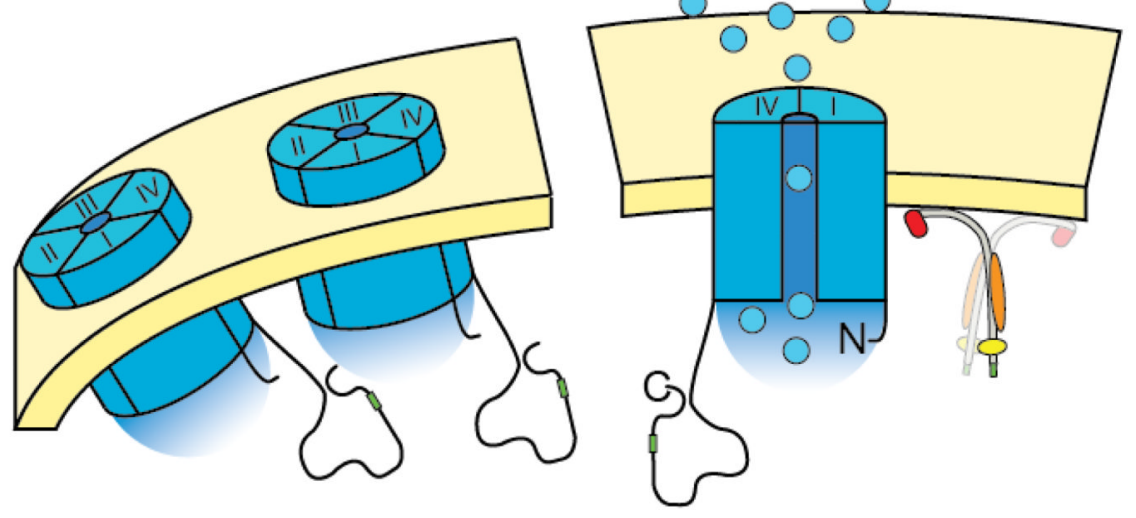

$\left[\begin{array}{l}\Delta\left[\mathrm{Ca}^{2+}\right]_{\mathrm{i}} \\ \text { Low }\end{array}\right.$
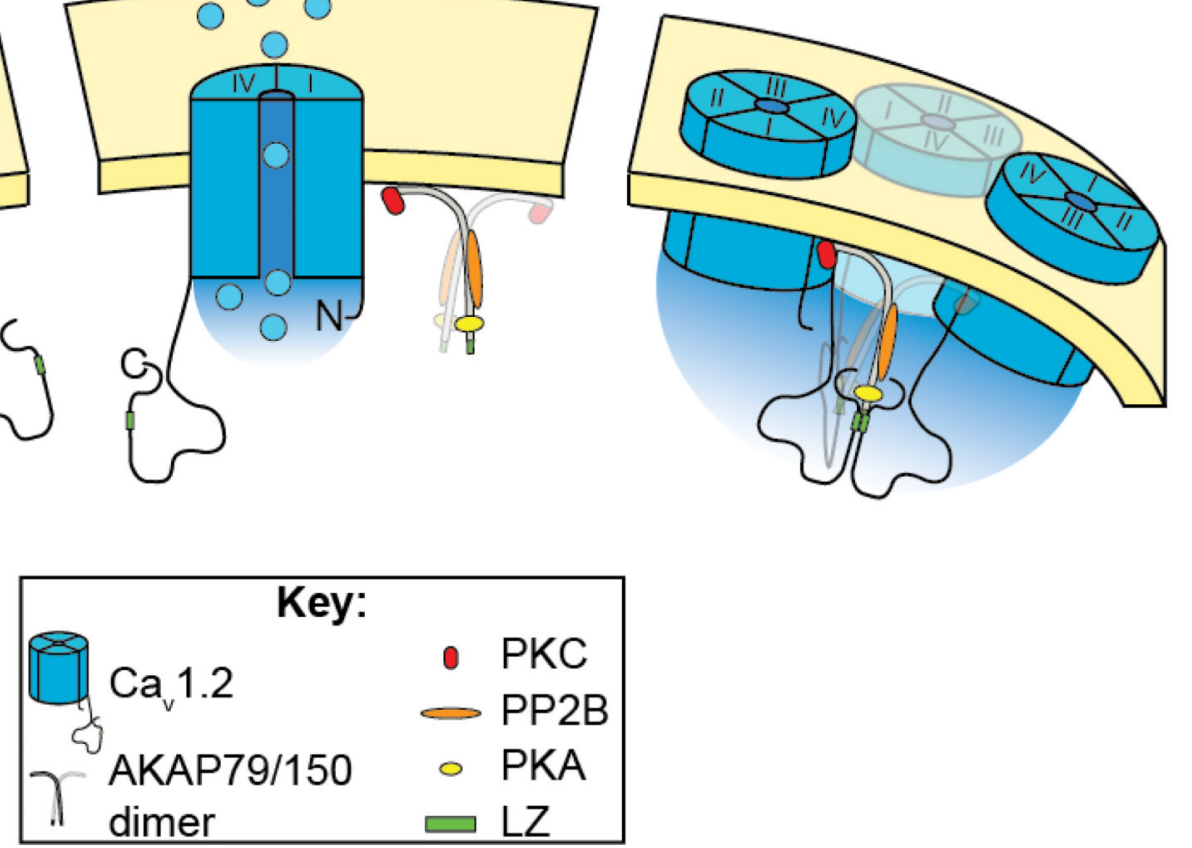

Figure 3. Our working model

Illustration of our working model showing that physical interaction between adjacent $\mathrm{Ca}_{\mathrm{V}} 1.2$ via LZ motifs on their C-termini permits coordinated gating of clusters of $\mathrm{Ca}_{\mathrm{V}} 1.2$ channels, leading to amplification of $\mathrm{Ca}^{2+}$ influx. We propose that AKAP79/150 stabilizes the interaction via a partial $\mathrm{LZ}$ motif on its $\mathrm{C}$-terminus. 